\title{
4
}

\section{An Age of the Mandarins? Government in New Zealand, 1940-51}

\author{
John R. Martin
}

The passage of more than half a century allows us to view the period following the end of the Second World War until the 1950s genuinely as history. Research materials, principally in archives, are supplemented by official histories, and biographies, with a few interviews enriching the story. I have been struck by the number of leading public servants of the period who were still in office during the 1950s and 1960s and who influenced the public service in which I spent 35 years. I was privileged to have known a number of them.

In this chapter, after sketching the political and economic situation in New Zealand in 1945, I identify two principal challenges - managing the economy and national development - facing the Labour Government led by Peter Fraser. I also examine changes in organising government business made after the National Government came to office late in 1949. I then describe briefly the state of the public service as New Zealand emerged from the war. I consider the role played by several prominent public servants - a team to set against the Seven Dwarfs and reflect on what we know about their working relationships with ministers.

In essence, the picture is, first, of a group of outstanding and long-serving public servants who worked very closely with Prime Minister Fraser and his deputy, Walter Nash, the minister of finance, through the war and afterwards. With the change of government in 1949, the close, personal and somewhat haphazard methods of working under Labour were succeeded by a more conventional (in the Westminster model) relationship between ministers and officials, conducted within a more formal machinery for the handling of Cabinet business - a change sought unsuccessfully by officials when the Labour Government was in office. ${ }^{2}$

\footnotetext{
1 In writing this chapter I have benefited greatly from discussions with Dr Brian Easton, Professor Gary Hawke, Sir Frank Holmes and Mr Noel Lough. Needless to say the responsibility for what is said rests entirely with me. I have also gained much from two books by a Canadian scholar, J.L. Granatstein, The Ottawa Men: The Civil Service Mandarins (Toronto: Oxford University Press, 1984); A Man of Influence: Norman A. Robertson and Canadian Statecraft 1929-68 (Deneau Publishers, 1981).

2 A recent discussion of New Zealand's constitutional arrangements in the immediate post-war period is H. Kumarasingham, Onward with Executive Power: Lessons From New Zealand 1947-57 (Wellington: Institute
} 
The Seven Dwarfs and the Age of the Mandarins

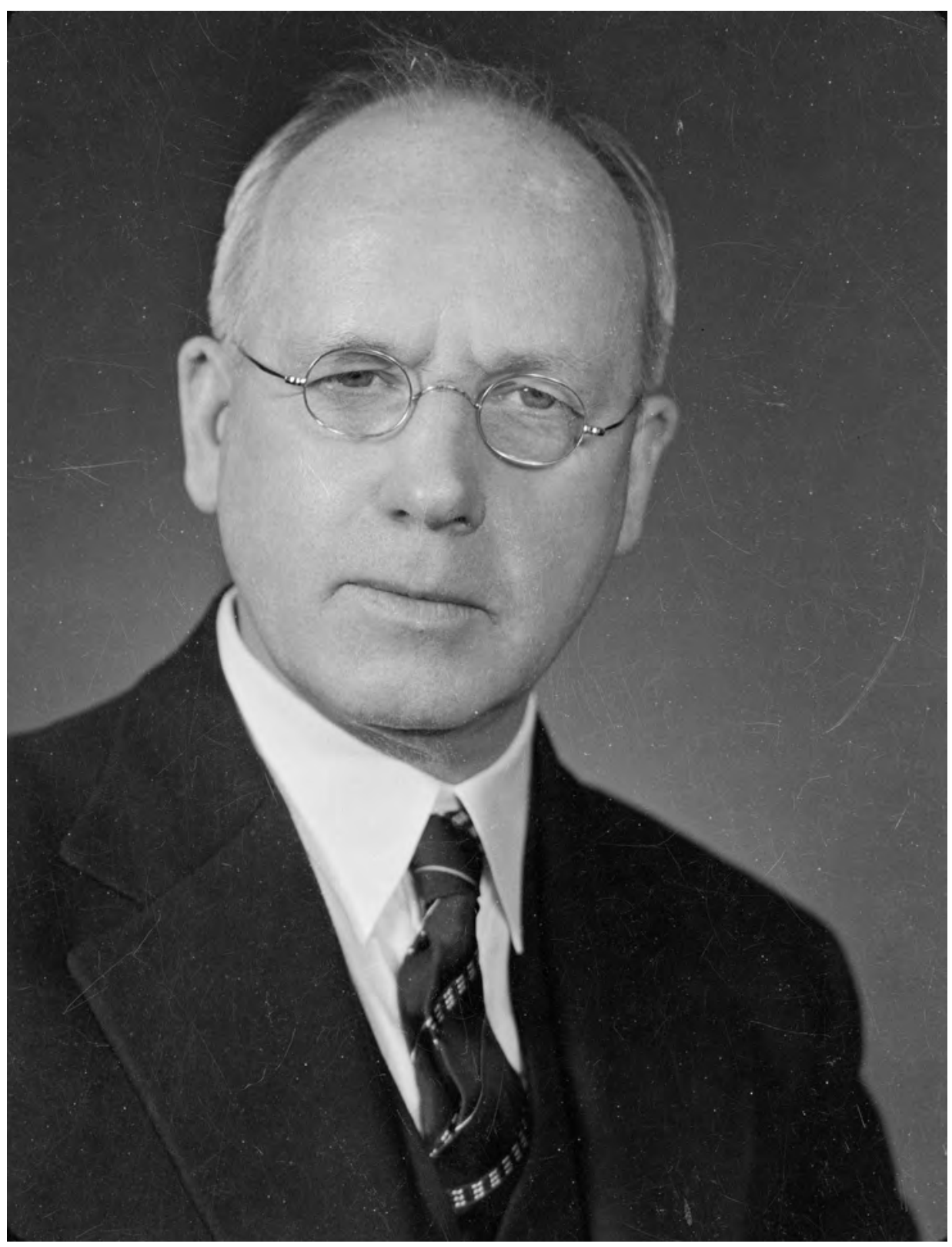

\section{Peter Fraser, c1940}

Source: S.P. Andrew Collection, Alexander Turnbull Library

of Policy Studies, 2010) 
I conclude with reflections about the influence that the immediate post-war period had on New Zealand public administration at least until the 'revolution' of the mid-1980s. This was, in part, a matter of personalities: the heads of departments in the 1960s and 1970s were the 'bright young men' of such agencies as the Economic Stabilisation Commission of the 1940s; they were shaped by the mandarins of that period and, in turn, guided key public servants of the 1970s and 1980s. Beyond personalities, the 'mildly corporate' style of government some would say, in Keith Middlemas' phrase, 'corporatist bias' ${ }^{3}$ - that persisted for nearly half a century owed a great deal to the conventions and arrangements that emerged during the war and in the transition to peace.

\section{Setting the scene}

New Zealand entered the Second World War in a state of 'economic emergency'. ${ }^{4}$ Although commodity prices had improved since the mid-1930s, increased imports (flowing from expanded government activity and guaranteed dairy prices) and an upturn in capital withdrawal during 1938 led to an exchange crisis. In December 1938 import and exchange controls were imposed; they remained in place with variations for five decades. After long and humiliating discussions in the City of London seeking to roll over maturing loans, the minister of finance, Walter Nash, returned to New Zealand the day after war was declared.

New Zealand was radically different at the end of the war. Exchange reserves were in a healthy state and loans had been repaid. In 1947, the 'Government and people of New Zealand' were in a position to make a 'gift' ${ }^{5}$ of $£ 10$ million sterling to the United Kingdom. Export income had been enhanced through bulk purchase agreements under which the United Kingdom purchased exports of meat, dairy products and wool at guaranteed prices. These arrangements remained in place until the 1950s. Imports had been restrained. Fiscal and monetary policies were deflationary ${ }^{6}$ and based on 'sound finance'. Crucially they were complemented by stabilisation measures - income and price controls

\footnotetext{
3 In the British context, 'the tendency of industrial, trade union and financial institutions to make reciprocal arrangements with each other and with government while avoiding overt conflict'. Keith Middlemas, Power Competition and the State, Vol. 1 (London: Macmillan, 1986), 1.

4 J.V.T. Baker, The New Zealand People at War: War Economy (Wellington: Historical Publications Branch, Department of Internal Affairs, 1965), 2. I am indebted to Baker, and also to G.R. Hawke, The Making of New Zealand: An Economic History (Cambridge: Cambridge University Press, 1985); and B. Easton, In Stormy Seas: The Post-War New Zealand Economy (Dunedin: University of Otago Press, 1997) for their discussions of the New Zealand economy before, during and after the war.

5 The 'gift' was not only an act of generosity; it was linked with negotiations on sterling and bulk purchase. 6 Hawke, The Making of New Zealand, 172. Price rises in New Zealand between 1939 and 1945 at 18 per cent (and 5 per cent during the stabilisation period from 1942 to 1945) were significantly below the United Kingdom and United States, and Australia (23 per cent).
} 
- that were supported by a 'willingness of groups within the community to subordinate their interests to the perceived need for resources to be mobilised towards the war'. ${ }^{7}$ The machinery of stabilisation and the thinking behind it influenced both economic management and the style of government for many years to come.

New Zealand's first Labour Government held office throughout the war and for four years afterwards - a total of four parliamentary terms. It had won in a landslide at the general election at the end of 1935 and remained in office until 1949. It was led, first, by Australian-born Michael Joseph Savage. He died in 1940 and was succeeded by Peter Fraser, who headed the government for nine years until the National Party led by Sydney Holland defeated it. Fraser, as prime minister and minister of external affairs, and Walter Nash, as deputy prime minister and minister of finance, dominated the Cabinet throughout the war and in the immediate post-war years. Their distinctive styles of leadership and their relations with the public service are considered below.

When Labour came to office, New Zealand was emerging from the Depression. Ministers had no hesitation in using the state as the engine of development. Extensive public works programs (notably roads, housing and hydro-electric power development) got under way. Benefits were increased. Industrial relations legislation was amended to improve the position of workers and unions. Guaranteed prices for dairy products were introduced. The Industrial Efficiency Act 1936 signalled the government's commitment to 'the promotion of new industries in the most economic form'. And, in 1938, passage of the Social Security Act 'restored New Zealand's status as a social laboratory' ${ }^{8}$ and laid the foundations of the modern welfare state.

Mobilisation of the country for war of necessity further extended the role of the state, facilitated by the existence of widespread controls already in place. The wartime framework of public agencies and regulatory instruments was available to the Labour Government to pursue national development in the post-war period.

\section{The post-war challenges}

Like all other countries that had been engaged for five years in total war, New Zealand had immediate issues with which to deal in making the transition to peacetime. Employment was at the forefront. Returning servicemen needed to find jobs; the place in the workforce of women (who had filled the gap left by

7 Ibid.

8 P.M. Smith, A Concise History of New Zealand (Melbourne: Cambridge University Press, 2005$), 157$. 
men called into the forces) required attention - a particular issue for the state services; and 'manpower' controls had to be unwound. Unlike the situation after the Great War, the shortage of labour after the Second World War was 'to make the problem of rehabilitation comparatively simple'. ${ }^{9}$ Indeed, the persistence of 'full employment' ${ }^{10}$ - most economists at the time and later would say 'over-full employment' - and the consequential threat of inflation preoccupied policymakers in the post-war period.

To illustrate the nature and style of governance in New Zealand in the post-war years I have focused on economic management (the short term) and national development (the long term). But there were also activities of interest in other fields of public policy - and the public service - to which I will allude below.

\section{Economic management}

At what point was the influence of Keynes on New Zealand economic management felt? We know that when the minister of finance, W. Downie Stewart, and the secretary to the Treasury, A.D. Park, were in London in 1932, they met Keynes who offered views on New Zealand's exchange problem (including 'to approximate the Australian rate of exchange'). ${ }^{11}$ We know, too, that Keynes' ideas (The Means to Prosperity) ${ }^{12}$ - to stimulate growth through increased government spending - influenced representations to the minister of finance, Gordon Coates, ${ }^{13}$ early in the 1930s, but were dismissed as irrelevant. Keynesian views on the place of 'cheap money' (low interest rates) were understood by officials such as Ashwin (see below) and shared by the apostles of Douglas Credit. ${ }^{14}$ But the influence of economists on the New Zealand governments of the 1930s was largely confined to recommendations to devalue the New Zealand pound against sterling that came from a government-appointed committee in 1932. The New Zealand Treasury was more inclined to deal with bankers and businessmen than economists.

\footnotetext{
9 Baker, The New Zealand People at War, 504.

10 Hawke, The Making of New Zealand, 190. After the Second World War and until 1967 not more than 0.2 per cent of the labour force was registered as unemployed.

11 M. McKinnon, Treasury: The New Zealand Treasury 1840-2000 (Auckland: Auckland University Press in Association with the Ministry of Culture and Heritage, 2003), 137. Downie Stewart, who resigned his ministerial post when the Cabinet decided to devalue, described Keynes in his diary as 'a peculiar looking man, very tall, with dark hair and black moustache'.

12 J.M. Keynes, The Means to Prosperity (London: Macmillan, 1933).

13 J.G. (Gordon) Coates (1878-1943), Reform Party prime minister between 1925 and 1928, was minister of finance in the Coalition Government between 1933 and 1935. He served in the war cabinet from 1940 until his death in 1943.

14 Hawke, The Making of New Zealand, 154.
} 
The Seven Dwarfs and the Age of the Mandarins

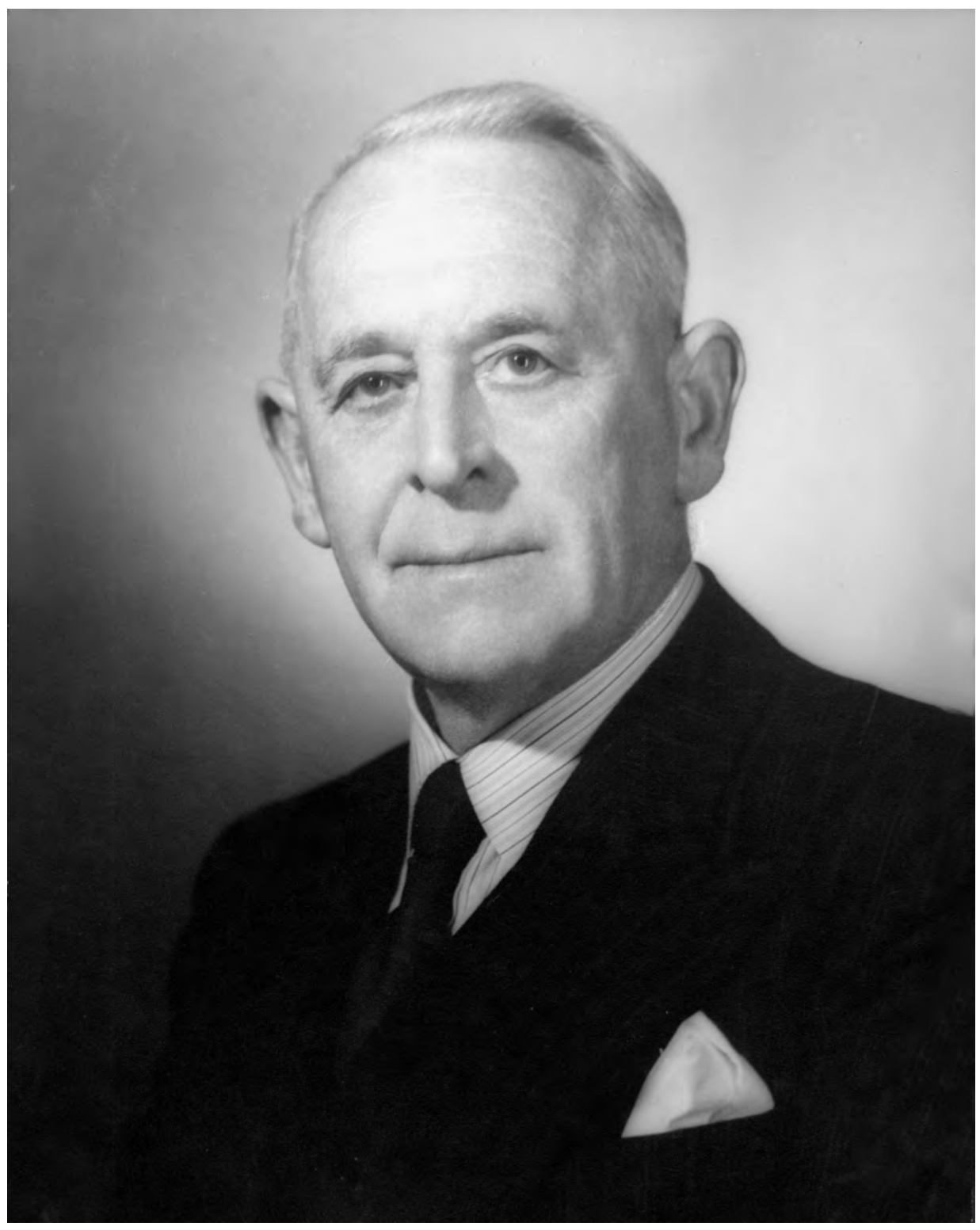

B.C. (Sir Bernard) Ashwin, c1955

Source: New Zealand Treasury 
There is no evidence that the influence on economic policy of economists, Keynesian or otherwise, increased after Labour assumed office in 1935. Indeed, McKinnon, in his history of the New Zealand Treasury, contrasts the 'movement of young Keynesians into other British Commonwealth Treasuries' with their absence from the New Zealand Treasury. In particular, the 'exciting' experience of H.C. Coombs in Australia in the mid-1930s is recalled. ${ }^{15}$

At this point the first of the 'mandarins' around which this chapter is constructed enters the narrative. B.C. (later Sir Bernard) Ashwin had been an influential adviser to the United/Reform Coalition Government, which held office from 1931 to 1935 , a period which included negotiations over establishment of the Reserve Bank. Although Ashwin did not become secretary until 1939 - at the age of 42 - there is no disagreement with the proposition that he was the principal official advising New Zealand governments on economic management from the early 1930s until his retirement in 1955.

Brian Easton, writing about Ashwin as one of New Zealand's nation-builders, states that he was the Treasury's only economist in the 1930s. ${ }^{16}$ Ashwin had graduated as a Master of Commerce in economics in 1925 from Victoria University (part-time study). He was a member of the Economic Society of Australia and New Zealand from the 1920s and a contributor to the Economic Record.

Ashwin worked in close association with the Labour Government throughout its long period of office. Walter Nash was the minister of finance for the entire 14 years. Ashwin was deeply involved in the Social Security Act 1938 (seeking to moderate the claims on the public purse); in buying out the private shareholders in the Reserve Bank and increasing the Bank's powers over the trading banks; in the exchange crisis of 1938-39, meeting ministers daily while negotiations proceeded in London; and in the various aspects of what is generally accepted to be a 'symbolic' new direction of economic management that can be dated from the decisions in December 1938 to impose import and exchange controls that continued long after the initial crisis. ${ }^{17}$

'Insulationism' (or 'planned insulation') ${ }^{18}$ was the term in use from the late 1930s through to the post-war period to represent 'a broad decision that the course of the New Zealand economy should be determined less by events overseas and more by the choice of local people, especially those holding official positions' ${ }^{19}$ By contrast, with the onset of the Depression in 1930, the government at the end of the war in 1945 had at its command not only the levers of fiscal policy, but

15 McKinnon, Treasury, 159, citing G. Whitwell, The Treasury Line (Sydney: Allen \& Unwin, 1986), 10, 11, 61-5.

16 B. Easton, The Nationbuilders (Auckland: Auckland University Press, 2001), 47.

17 Hawke, The Making of New Zealand, 163.

18 J.B. Condliffe, The Welfare State in New Zealand (London: Geo. Allen \& Unwin, 1959), 58.

19 Hawke, The Making of New Zealand, 163. 
also control of monetary policy (through the Reserve Bank and, in theory, the ownership of the Bank of New Zealand - nationalised in 1945 and responsible for 40 per cent of banking business), import, exchange and price controls, and, in effect, an incomes policy through the instrument of the Arbitration Court.

The Reserve Bank, established in 1934, perhaps surprisingly, does not feature prominently in this story. In matters of general monetary policy, Ashwin was undeniably the principal adviser:

He had been prominent in the foundation of the bank, and he looked on it as to some extent his child. But he considered that it had had an unfortunate beginning and he did not regard it as playing a major role in economic policy in the 1940s. By the late 1940s and the early 1950s ... Ashwin was too well established as the senior financial adviser to Government to regard the bank as a rival ... ${ }^{20}$

The role of the Arbitration Court warrants recognition here. The Court (a judge flanked by nominees of the social partners, the employers and unions), with its power to issue general wage orders, played a significant role in the economy. Judge Arthur Tyndall shared a number of characteristics with other 'mandarins' who feature in this chapter. He was a long-time public servant (an engineer, lawyer and accountant). After some years in road construction, he was successively secretary of Mines (1934-36), and director of Housing (1936-40) heading a flagship program of the Labour Government - becoming judge of the Arbitration Court in 1940 and remaining in that position until 1965.

In the words of J.B. Condliffe, one of New Zealand's most eminent economists, writing in 1959, '[t]he New Zealand economy emerged from the war taut with suppressed inflation'. ${ }^{21}$ With international reserves at very comfortable levels, a balanced budget, and the continuation of an assured market for primary products in the United Kingdom, there were pressures on the government to ease wartime restraints. But, by comparison with the situation when Labour assumed office a decade earlier, notable for under-employment, resources, including the workforce, were now fully employed. There was also an appreciation among the policy-makers of the

lesson of Keynesian economics that fiscal policy could be used to balance aggregate demand and supply in the economy as a whole, and that the

\footnotetext{
20 G.R. Hawke, Between Governments and Banks: A History of the Reserve Bank of New Zealand (Wellington: Government Printer, 1973), 223. Particularly after Ashwin's retirement in 1955 and on the technical aspects of monetary policy E.C. Fussell (deputy governor, 1941-48 and governor, 1948-62) was a respected adviser.

21 Condliffe, The Welfare State in New Zealand, 99.
} 
budget was not merely a matter of government housekeeping. But this was grafted on to an economy where official controls were widespread and not regarded as a transitory phenomenon. ${ }^{22}$

At the centre of the government machinery that administered this web of controls was the Economic Stabilisation Commission (ESC) - 'that very remarkable institution'. ${ }^{23}$ In December 1942, a comprehensive economic stabilisation scheme was announced and a six-person commission established with Ashwin as director of Stabilisation. Ashwin took over as chair of a threeperson commission in July 1943. ${ }^{24}$

The ESC had what may now seem to be a disproportionately large influence on economic policy making and public administration during the next 30 years. First, as an 'independent semi-representative body' ${ }^{25}$ it demonstrated the 'mildly corporate $^{26}$ nature of New Zealand politics that persisted until the Rogernomics revolution in the 1980s. One interpretation is that 'the government was engaged in an elaborate piece of social engineering. Ministers were attempting to construct a wartime economy that would treat all sections as fairly as possible' ${ }^{27}$ The government - represented by Ashwin - was in the chair flanked by F.P. Walsh ${ }^{28}$ representing the Federation of Labour and a representative of the farming industries. This was an expression of the agreement between the trade union movement and the farmers underpinning the stabilisation policy of the government. The unions, notably the Federation of Labour, and farming, through the producer boards and Federated Farmers, carried a great weight in determining economic policy through the next four decades. ${ }^{29}$

\footnotetext{
22 Hawke, The Making of New Zealand, 173.

23 L.C. Webb, 'The Making of Economic Policy', in R.S. Parker, ed., Economic Stability in New Zealand (Wellington: NZIPA, 1953), 24.

24 In some respects there is an affinity between the ESC and the Australian 'F and E' (the Financial and Economic Advisory Committee) - see Whitwell, The Treasury Line, 65-79.

25 M.J. Moriarty, 'Administering the Policy of Economic Stabilization', New Zealand Journal of Public Administration, 7, no. 2 (March 1953), 30.

26 A term attributed to John Roberts, Professor of Public Administration at Victoria University of Wellington (1966-88). Roberts also wrote about 'the stabilization game' - 'a symbolic construction of policy consensus among a broadly dispersed political elite' - a consensus of 'fair shares'. See John Roberts, 'Society and its Politics', in Thirteen Facets: Essays to Celebrate the Silver Jubilee of Queen Elizabeth the Second 1952-77 (Wellington: Historical Publications Branch, DIA, 1978).

27 M. Bassett and M. King, Tomorrow Comes the Song: A Life of Peter Fraser (Auckland: Penguin, 2000), 202.

28 G. Hunt, Black Prince: The Biography of Fintan Patrick Walsh (Auckland: Penguin Books, 2004), 133. Fintan Patrick Walsh (1896-1963), a founding member of the Federation of Labour and president from 1953, and member of the ESC (1942-50). His key role in economic policy making in the immediate post-war period is exemplified by the publication of Economic Stabilization in the Post-War Period in early 1946. Soon known as 'The Walsh Report' but written by ESC officials, Lloyd White and Alan Low, the report warned of the dangers of inflation. Walsh, with Fraser's endorsement, 'sold' the report to reluctant trade unions.

29 This proposition as it applies to the union movement may be challenged by citing the conflict with the National Government that reached its peak in the waterfront strike of 1951 followed by a 'snap' general election. The industrial relations system based on the Arbitration Court remained, however, and the Federation of Labour without doubt had a very large influence on the administration of the 1960s, 1970s and early 1980s.
} 
Secondly, the commission played an important role 'in easing the pressure on the political executive: it carries out negotiations on prices and payouts with representatives of the farming industries, the manufacturing industries, and other economic interests'.$^{30}$ McKinnon suggests that negotiations at the level undertaken by the ESC in New Zealand were carried out by ministers in the United Kingdom, Canada and Australia (cf. the role of the Australian price stabilisation committee). ${ }^{31}$

Thirdly, the ESC reached across the whole range of government agencies. While other tribunals and departments administered the regulations on prices, wages, goods and services - there were 18 controllers in the Ministry of Supply and Munitions - the commission called the shots. As Moriarty wrote at the time:

Economic Stabilization covers prices, wages, rents, transport - in fact every economic activity of the individual. The Departments dealing with these activities all have problems which are also the concern of the Commission. The Commission is the central intelligence and 'economic general staff' service for the Government. It must maintain contact, through its officers, with the various departments dealing with economic affairs, recommend particular courses of action which it believes to be in harmony with the general policy, and withal keep the Government continually informed of the economic state of the country. ${ }^{32}$

The ESC in this respect clearly foreshadows the coordinating role of the Treasury in future, both as the 'principal economic and financial adviser' and as chair and secretariat of the Officials Economic Committee structure that developed in the 1940s and took a central place in economic decision-making (see below).

Fourthly, the ESC was a fruitful training ground for a remarkable number of public servants $^{33}$ who would lead the public service in the 1960s and 1970s (as well as Robert Parker ${ }^{34}$ and Leicester Webb, ${ }^{35}$ who had distinguished academic careers

30 L.C. Webb, 'Politics and Administration', in Horace Belshaw, ed., New Zealand (Berkeley: University. of California Press, 1947), 288.

31 McKinnon, Treasury, 173.

32 Moriarty, 'Administering the Policy of Economic Stabilization', 30.

33 Among the names are: M.J. Moriarty (secretary of Industries and Commerce, 1965-72), H.G. Lang (secretary to the Treasury, 1968-76), N.V. Lough (secretary to the Treasury, 1976-80), Sir Alan Low (governor, Reserve Bank, 1967-77), G.D.L. White (deputy secretary, Foreign Affairs, 1964-72, Ambassador, Washington, 1972-78), A.C. Shailes (controller and auditor-general, 1975-83), K.C. Durrant (deputy director-general, Ministry of Agriculture and Fisheries, 1969-82).

34 R.S. (Robert) Parker was lecturer in public administration at Victoria University College, Wellington from 1939 to 1945, with some years in war service (including time at the Economic Stabilisation Commission), and returned as professor of political science from 1949 to 1954 when he took up the position of reader (later professor) in political science at The Australian National University.

35 Leicester Webb (1905-1962), after a career in journalism and study in Europe, became director of stabilisation from 1945 to 1948 and later professor of political science at The Australian National University. See J. Warhurst, 'Leicester Webb and the Foundation Years of Australian Political Science', Australian Journal of Political Science, 37, no. 3 (November 2002). 
in Australia). The staff of the ESC featured a number qualified in economics - the Treasury was then, and for a decade into the future, predominantly a department of accountants. But this was a generation of public servants whose formative years were spent in an environment of regulation born not of ideology but of a pragmatic resort to the apparatus of the state to deal with the problems of the day. Such an approach was not incompatible with an underlying belief in the virtues of markets. This eclectic approach characterised the policy stance of people like Moriarty and Lang throughout their influential careers. The commission itself became an advisory committee to the minister of industries and commerce in 1948. It was abolished in 1950 and a number of the staff (including Moriarty, Lang and Lough) transferred to the Treasury.

The heyday of the ESC also marked the dominance of Ashwin within the Wellington governance system. ${ }^{36}$ This dominance was starkly emphasised between 1942 and 1944 when Walter Nash, although remaining minister of finance, was also resident minister in Washington DC. While his central role in the business of government remained, in the last years of the Labour Government Ashwin was not always successful in persuading ministers to avoid inflationary spending. Although the head of the Prime Minister's Department, Alister McIntosh, told Sir Norman Brook, secretary to the Cabinet in the United Kingdom, in February 1950, that the "Treasury have succeeded all too well in scaring the new Government stiff', Ashwin apparently fell out with Holland in his final years. ${ }^{37}$

Among the major economic events that stand out in the five years following the war are the decision in 1948 to revalue the New Zealand pound to parity with sterling, and the Korean War commodity boom in 1950-51 - after Labour had been defeated at the polls and the National Party had begun its uninterrupted period of eight years in office. Many wartime controls were relaxed in Labour's last years. In the early 1950s, the National Government, consistent with rhetoric about 'freedom', reduced price controls and limits on exchange payments and imports. Balance of payments pressures soon led to their tightening. Coupled with monetary controls, constraints at the frontier and regulation of prices and wages continued to mark economic management in New Zealand for the first four decades after the war.

Symbolising the readiness of successive governments to resort to regulatory powers when confronted by problems of economic management was retention until 1987 of the Economic Stabilisation Act 1948. This statute retained the wartime emergency powers of the Executive to 'control prices, wages, and take almost

36 While Ashwin was secretary to the Treasury he also served as director of the Reserve Bank; director of the State Advances Corporation; chairman of the Local Authorities Loans Board; member of the Dairy Products Marketing Board; and, during the war, paymaster-general of the armed forces.

37 McKinnon, Treasury, 216. 
every economic measure conceivable (short of raising taxes) by regulation' ${ }^{38}$ Around 200 regulations were made under the authority of this Act. As Sir Robert Muldoon said in 1976, 'you can do anything provided you can hang your hat on economic stabilisation'. ${ }^{39}$

Associated with such controls were policies of industrialisation ${ }^{40}$ - behind the mechanisms of 'import selection' or 'import substitution' - central to the broader objective of national development. In this respect, Hawke's observation is apposite. He notes that the best reason for import licensing 'was probably that it was desirable to have a variety of industries so as to provide opportunities for New Zealanders to develop a range of skills and aptitudes' and that the alternative, quoting Drummond ${ }^{41}$ on industrialisation programs in general, was:

A small scattered population of farmers, shepherds and miners, a few market towns, a scanty clutch of civil servants, lawyers, doctors and clerics. New Zealand in 1900 in fact. Or Gold Coast in $1950 .{ }^{42}$

\section{National development}

Above all, New Zealand was a 'dependent economy'.${ }^{43}$ After the war a 'programme of planned development behind the insulation of exchange control' ${ }^{\prime 4}$ could be $^{2}$ built on the foundations put in place in 1938 and later extended. New Zealand's national development in the 1940s and 1950s had three principal components. First, increased productivity in the farming industries (these were the years of aerial topdressing, irrigation, and application of state-funded scientific innovation to the grasslands); second, enhanced infrastructure; and, thirdly, industrialisation.

Expanded public works activity was a key element in Labour's pre-war program: roading, hydro-electric power generation, airport development, irrigation schemes and housing projects. All resumed after the cutbacks of the Depression. But the outbreak of war diverted resources to military requirements. The Public Works Department became increasingly 'the constructional agency of the armed

\footnotetext{
38 G. Palmer and M. Palmer, Bridled Power (3rd edn Auckland: Oxford University Press, 1997), 171.

39 Ibid., 172.

40 See S. Leathem, 'Industry and Industrial Policy', in H. Belshaw, ed., New Zealand (Berkeley: University of California Press, 1947) and Michael Bassett, The State in New Zealand 1840-1984: Socialism without Doctrines? (Auckland: Auckland University Press, 1998), 208-10.

41 I.R. Drummond, "The British Empire Economies in the "Great Depression"”, in H. van der Wee, ed., The Great Depression Revisited: Essays in the Economics of the Thirties (The Hague: Martinus Nijhoff, 1972), 233.

42 G.R. Hawke, Government in the New Zealand Economy, Planning Paper No. 13 (Wellington: New Zealand Planning Council, 1982), 44.

43 H. Belshaw, 'Stabilisation in a Dependent Economy', Economic Record Supplement, April 1939; C.G.F. Simpkin, The Instability of a Dependent Economy: Economic Fluctuations in New Zealand, 1840-1914 (London: Oxford University Press, 1951).

44 Condliffe, The Welfare State in New Zealand, 63.
} 
services' ${ }^{45}$ The extent of military requirements and the claims from overseas theatres on manpower and equipment were an unparalleled challenge. The departmental structure was demonstrably inadequate and, from March 1942, wartime arrangements were put in place.

A Defence Construction Council was established with the prime minister as chairman and with the newly appointed commissioner of defence construction as vice-chairman. This latter appointment, with sweeping powers, had a significant influence on post-war organisation of public works. James (later Sir James) Fletcher, the founder of what is still a major construction company, had been a dominant figure in the government's state housing schemes. He was instrumental in creation of a new statutory agency - the Ministry of Works ${ }^{46}$ - to 'establish more appropriate control over the execution of all construction works, including housing construction', and became the first commissioner of works. The Ministry, separate from the Public Works Department (PWD), worked with the Treasury in examining the economic and technical aspects of all projects from central government agencies, local government or subsidised from the public purse. Responsibility for carrying out public works remained with the PWD.

It was envisaged from the outset that the ministry would continue after the war and, from 1946, the commissioner of works took over the responsibilities of the permanent head of the PWD. Thus was born the Ministry of Works, the powerful department that played such a major part in New Zealand's development until its demise during the 1980s 'Revolution'.

From its inception the ministry - and its minister, the redoubtable Robert Semple - aspired to a 'planning' role. Semple, indeed, referred to it as the Ministry of Works and Planning. ${ }^{47}$ He spoke of the haphazard way in which public works had proceeded and of 'political roads and bridges'. Initially, it was envisaged that Fletcher as commissioner would supervise the execution of a plan for postwar recovery approved by Cabinet. Some credence was given to the 'planning' function of the ministry when administration of the Town Planning Act 1926 was transferred from the Department of Internal Affairs to the Ministry of Works in 1946 (the Act was not amended until 1948). The Town and Country Planning Branch was an integral part of the ministry until the 1980s.

Despite Semple's claims, there was some uncertainty about where 'planning' should be located in the governance structure of the post-war period. Early in 1944 Cabinet established the Organisation for National Development

45 R. Noonan, By Design: A Brief History of the Public Works Department, Ministry of Works 1870-1970 (Wellington: Government Printer, 1975).

46 Ministry of Works Act 1943.

47 Noonan, By Design, 188. 
(OND) as a branch of the Prime Minister's Department - the counterpart to Australia's Department of Post-War Reconstruction. The initiative seems to have come from the Department of Industries and Commerce (and Ministry of Supply) that carried the major burden of administering wartime controls. The mandate was 'not only to study and plan for long-range development of the Dominion but also to make special preparation for practical measures to meet the period of transition which will occur on the cessation of hostilities. ${ }^{48}$ The Organisation itself, working within policy set by a Cabinet sub-committee of the prime minister, and the ministers of Finance, Industries and Commerce, Works, Agriculture, and Rehabilitation, consisted of a chief executive officer, a coordinating committee of five permanent heads (chaired by Ashwin), and a small research staff. Planning was to be undertaken by a series of committees chaired by ministers: construction, power development, rehabilitation and personnel, transport, tourism and publicity, immigration and labour, imports and shipping.

On 19 November 1945, Cabinet disbanded the OND. Cabinet committees already established would deal with any 'major problems involving rehabilitation and post-war reconstruction'. The executive committee was replaced by a special departmental committee chaired by the secretary to the Treasury 'and making recommendations to Cabinet whenever necessary'. Various planning committees continued at the discretion of the appropriate responsible minister. The Ministry of Works would assume all 'physical planning functions'. Regional councils set up under the auspices of the OND were 'to take full responsibility for managing their own affairs'.$^{49}$

Polaschek, writing in 1958, assessed the OND as having 'accomplished a good deal' despite its short life, specifically important surveys of coal mining and forestry, population estimates and demobilisation plans.

Nevertheless, New Zealand governments must face an election every three years. This coupled with their typical pragmatic approach to problems gives them a preference for action rather than plans. So the existence of a purely planning body divorced from the carrying out of policy is always likely to be precarious. Particularly is this so if its functions cut across those of old established departments, like Treasury and Works, which are concerned both with forming policy and applying it. ${ }^{50}$

48 Hon. D.G. Sullivan (Minister of Industries and Commerce and acting Prime Minister) announcing the establishment of the Organisation for National Development in 1944 (quoted by Leathem, 'Industry and Industrial Policy', 174).

49 Archives New Zealand, AAFD 816/1, Shanahan's personal file on Cabinet organisation.

50 R.J. Polaschek, Government Administration in New Zealand (Wellington: New Zealand Institute of Public Administration, 1958), 49. 
The OND failed, in Polaschek's view, 'primarily because too much was expected from it too soon' - in announcing its demise to the House of Representatives, Fraser spoke of impracticability; he wanted quick results - but also 'because it cut across the lines of departmental authority and responsibility'.$^{51}$ Permanent heads were already overburdened. This is consistent with Sutch's comments that underline the location of power in Wellington:

Sullivan [Minister of Industries and Commerce] as Acting Prime Minister, established the OND early in 1944, when Nash was busy as New Zealand Minister in Washington and Fraser was at a war conference. When Fraser returned to find an economic planning group in his own department he was more than displeased and by 1946 he had disbanded it. He was supported in his action by the older and stronger government departments, for example, Treasury and Works, but had he wanted to, Fraser could easily have made an economic unit the most important part of the machinery of state. ${ }^{52}$

Similar impressions were recorded in a discussion in 1964 of a paper by Foss Shanahan (see below). ${ }^{53}$ There was a feeling that the OND had been 'suffocated' by senior officials in the Ministry of Works and the Treasury, 'partly because it sought to interpose itself between major Departments and their Ministers, partly because it seemed to usurp departmental responsibility for implementing plans, partly because its plans (which were not always discussed with departments responsible) were too ambitious and unreal, and partly because the youth and experience of some of its officers caused jealousies' ${ }^{54}$

As 'indicative planning' came into vogue in the 1950s and 1960s - the New Zealand manifestations are found in sectoral planning conferences, the National Development Conference (1968-72) and the New Zealand Planning Council (1977-91) - there were echoes of the issues that surrounded the OND.

\section{Cabinet and coordination}

Leicester Webb, writing in 1940, observed that:

It might be expected that, notwithstanding the variety of a cabinet minister's work, it would be possible for a dozen men to govern New

\footnotetext{
51 Ibid., 270.

52 W.B. Sutch, The Quest for Security in New Zealand 1840-1966 (Wellington: Oxford University Press, 1966), 345, 346.

53 F. Shanahan, 'Planning in War and Peace', in J.P.M. Cornwall, ed., Planning and Forecasting in New Zealand (Wellington/London: NZIPA/Oxford University Press, 1965), 19-32.

54 Cornwall, Planning and Forecasting, 10.
} 
Zealand, which has fewer inhabitants than Liverpool, is not troubled by racial minorities, and has no pressing problems of foreign policy, without shortening their lives by overwork and lack of sleep and without creating around themselves an atmosphere of flurry and crisis. But it is not so. The machinery of government in New Zealand works with as much jamming and overheating as the machinery of government in a great empire. ${ }^{55}$

Five years of war were years of achievement but, if anything, they highlighted the problems of the machinery of government suggested by Webb. At the ministerial level, the credit for achievement can largely be attributed to two people: Peter Fraser $^{56}$ and, to a lesser degree, Walter Nash. ${ }^{57}$ 'In effect, throughout the war, the key political decisions were made most of the time by two men. The pressure flicked from one to the other according to whichever was in New Zealand at the time. ${ }^{\prime 58}$ The situation did not change significantly in the aftermath of the war.

Fraser's health declined and both men conducted their business with a degree of idiosyncrasy that was the bane of officials. Fraser's sight was not good and officials, notably A.D. (later Sir Alister) McIntosh, head of the Prime Minister's Department and secretary of External Affairs, were on call late into the evening to read telegrams to him. Nash was a hoarder of files, a habit that continued in his one-term prime ministership between 1957 and 1960. These characteristics simply underlined the need, obvious to officials, for a more systematic conduct of government business. ${ }^{59}$

What detracted from an atmosphere of dignity in conducting cabinet meetings was [Fraser's] lamentable disregard for method and order. This led to endless rambling discussion and excessive waste of time with himself as the most notable offender leading the pack in the pursuit of many a hare. He just would not be organized. An agenda was an affront, and any attempt by an official or a colleague to introduce order would only make him mulish and antagonistic ... ${ }^{60}$

\footnotetext{
55 L. Webb, Government in New Zealand (Wellington: Department of Internal Affairs, 1940), 67-8.

56 For an account of Fraser in New Zealand politics see Bassett and King, Tomorrow Comes the Song.

57 For a similar account of the life of Nash see Keith Sinclair, Walter Nash (Auckland: Oxford University Press, 1976).

58 Bassett and King, Tomorrow Comes the Song, 223.

59 'For my part I wished that [Nash's] good intentions had not rested on his egregious inability to organise his work. As with Fraser, time meant nothing to Nash. As a Minister he boasted that he never went home on the day he left it ... Papers piled up in his office. They stayed there for days and weeks, or months or years, and sometimes forever ... This habit of holding papers caused serious dislocation of public business.' Sir Carl Berendsen in Hugh Templeton, ed., Mr Ambassador: Memoirs of Sir Carl Berendsen (Wellington: Victoria University Press, 2009), 7.

60 A.D. McIntosh, 'Working with Peter Fraser in Wartime', in M. Clark, ed., Peter Fraser: Master Politician (Wellington: Dunmore Press, 1998), 163 (reprinting a 1973 address by McIntosh). There is a resemblance to the practice of Mackenzie King in Canada: 'King's lack of, and aversion to, system.' Granatstein, The Ottawa Men, 203.
} 
But in the domestic Cabinet for which there was no secretariat, until after the end of the war, chaos often prevailed.

This provides an opportunity for introduction of three mandarins who made an indelible mark on the New Zealand public service. C.A. (later Sir Carl) Berendsen, 'an Australian New Zealander', departed from New Zealand as the first high commissioner in Canberra early in 1943 and retired as ambassador to the United States in 1952. But through the 1930s and until he left Wellington, he was the government's adviser on external affairs. From 1935, Berendsen was also permanent head of the Prime Minister's Department and, from June 1940, secretary of the War Cabinet. Berendsen was something of a one-man band. As his successor (McIntosh) commented, 'Berendsen had always been reluctant to take on staff not only because he was more competent than anyone else to handle the drafting and the decision-making involved but there was, in fact, no room physically within the Prime Minister's Department in Parliament Buildings in which to put staff' ${ }^{61}$

McIntosh, a librarian and historian, was effectively Berendsen's deputy in all roles. In 1943, at the age of 37, he became secretary of the War Cabinet and permanent head of the newly created Department of External Affairs. In 1945 he also became head of the Prime Minister's Department. He remained in the dual roles, heading the two departments, until 1966. McIntosh laid the foundations and built the department now known as the Ministry of Foreign Affairs and Trade, and guided New Zealand foreign policy for more than 20 years. ${ }^{62}$ He was at the right hand of four prime ministers - Fraser (for six years), Holland (for eight), Nash (for three) and Holyoake (for seven). It is his part in establishing the machinery that institutionalised the way in which New Zealand cabinets and officials have, in fundamental respects, functioned to the present day that is of interest.

Even more directly concerned with the organisation of Cabinet than McIntosh was the third of the trio of diplomat-cum-prime ministerial advisers, Foss Shanahan. A lawyer, Shanahan transferred from the Customs Department to the Prime Minister's Department in 1938 as assistant secretary to the Organisation for National Security (ONS), established within the Prime Minister's Department in 1937 to prepare the 'War Book'. In 1940, at the age of 30, Shanahan became

61 A.D. McIntosh, 'Origins of the Department of External Affairs and the Formulation of an Independent Foreign Policy', in New Zealand in World Affairs, Vol. I (Wellington: Price Milburn/NZIIA, 1977), 17.

62 McIntosh's place in New Zealand's administrative history is well covered in his published correspondence: Undiplomatic Dialogue: Letters Between Carl Berendsen and Alister McIntosh 1943-1952 (1993) and Unofficial Channels: Letters Between Alister McIntosh and Foss Shanahan, George Laking and Frank Corner (1999) both volumes edited by Ian McGibbon; McIntosh's own story of the early years in 'Origins of the Department'; McIntosh's speech accepting an honorary degree from Canterbury University in 1965, reprinted in M. Templeton, ed., An Eye, an Ear and a Voice: 50 Years in New Zealand's External Relations 1943-93 (Wellington: MFAT, 1993). 
secretary of the ONS. He then became assistant secretary to the War Cabinet and secretary of the Chiefs of Staff Committee and, in 1945, secretary to Cabinet and assistant (later deputy) secretary of External Affairs. In the 1950s Shanahan served abroad but tragically died at the age of 54 in 1964 (still deputy secretary of External Affairs, with McIntosh's retirement from the New Zealand public service only a couple of years away).

The archives tell a story of persistence by McIntosh and Shanahan in their efforts to persuade the government 'to establish a Cabinet Secretariat with a view to placing Cabinet business on an orderly basis, in contrast to the notoriously haphazard procedures which had characterised the War Cabinet ${ }^{63}$ - and the peacetime Cabinet.

In a file note of 30 September $1946,{ }^{64}$ Shanahan observed that the British Cabinet Secretariat 'had now, with experience in the Second World War, reached a very high stage of perfection' and that the Whitehall model was paralleled in Canada and Australia, particularly the former. Wartime experience, Shanahan argued, had emphasised the need for coordination among departments and the formal machinery in place on defence questions had proved its worth. But the work was more than one person could handle. The range of Cabinet standing committees recently established was serviced through arrangements organised by the minister in the chair. The 'weakness' of these committees was that 'they may trend [sic] in their discussions to proceed without the Ministers concerned always being informed of developments in sufficient time ... there is scope for a Cabinet Secretariat in New Zealand'.

A further paper of 5 June 1947 pointed to the number of important policy matters with which Cabinet must deal, some reorganization of the business could be effected so as to reduce the amount of time spent by Cabinet on matters not of the same relative importance' and again commended the British system and developments in Australia. ${ }^{65}$ Specific proposals were made for the approval of expenditure with delegation to individual ministers. A formal agenda should be circulated in advance. Ministers should be required to 'formulate precisely' recommendations and circulate papers five days in advance. Minutes on the British model should be prepared. The secretariat should check that effect had been given to decisions made by Cabinet.

\footnotetext{
63 McGibbon, Unofficial Channels, 28. A War Cabinet had been formed in July 1940 with three Labour members and two from the National Party. It was to deal not only with service matters but also production for war purposes, financing the war and generally to implement the policy of parliament in relation to New Zealand's participation in the war. This was not a 'national government' as the National Party Opposition was seeking: the Labour Cabinet continued as 'the government'. The War Cabinet held its last meeting on 9 August 1945 and, despite Holland's unwillingness to participate a degree of bipartisanship was achieved.

64 Archives New Zealand, AAFD 816/1, Shanahan's personal file on Cabinet organisation.

65 Ibid.
} 
McIntosh and Shanahan made little progress in the remaining days of the Labour Government in setting up a secretariat on the Whitehall model although Shanahan was present at Cabinet meetings from January 1948. The results of the 1949 general election presented the opportunity for officials to take the initiative.

In a memorandum of 2 December 1949 - between election day and the swearing in of the new government - McIntosh, acknowledging that this was 'substantially Mr Shanahan's draft', put before the prime minister-elect, Sydney Holland, a number of proposals 'to assist in the conduct of Cabinet business'. The memorandum:

presupposes that the concern of Cabinet with routine details would be reduced and the attention of Cabinet would be concentrated mainly on policy questions ... Ministers would be informed of problems before they were discussed and thus be in a better position to discuss them when they were being considered in Cabinet. Under a system where minutes were made and circulated the Ministers would be better informed and could better instruct Permanent Heads. ${ }^{66}$

McIntosh associated Ashwin and R.M. Campbell, chairman of the Public Service Commission, with his urgings

that some such procedure should be instituted, with a view not only to increasing the efficiency of the Cabinet itself but, more especially, to enabling the Public Service to carry out the policy decisions Cabinet wishes Government Departments to implement.

Shortly afterwards, Shanahan (who had been abroad and had spent time with Norman Robertson, secretary to Cabinet in Ottawa) made specific proposals to the prime minister relating to procedures for the agenda, minutes, expenditure control (on which Ashwin was reporting separately) and servicing Cabinet committees. Shanahan was not lacking in ambition for the Cabinet Secretariat. But the trouble-shooting role to which he aspired as Cabinet secretary perhaps emulating the dominance in Whitehall of Norman Brook (on whom he had called) - was not something that commended itself to such 'mandarins' as Ashwin in the Treasury or, it can be supposed, E.R. McKillop, the commissioner of works (1945-55). Although Shanahan, as deputy to McIntosh in the Prime Minister's Department and External Affairs, remained a powerful figure within the Wellington bureaucracy until his death, the Cabinet secretary and the secretariat were essentially there to service the Cabinet and its committees, a role executed efficiently and effectively, but not to set the directions for the path of government. 
A further definition - and restriction - of the role of the Cabinet Secretariat was associated with another important and long-enduring institutional innovation from the early post-war years. This was the Officials Economic Committee that became a central feature of the policy making machinery in Wellington for 30 years. The origins of this committee can be traced to a Balance of Payments Working Party formed in 1947 to forecast overseas exchange transactions (OET) in the context of the Sterling Area difficulties in the aftermath of the Second World War. ${ }^{67}$ Members represented the Treasury, the Reserve Bank, Industries and Commerce, Customs and Agriculture. ${ }^{68}$ It continued into 1949, focusing on OET forecasting and the import licensing schedule. After the change of government various arrangements were made to advise the Holland Government on economic matters including an Import Advisory Committee, and the Board of Trade. From 1952, the Cabinet Economic Committee, initially the Cabinet Committee on Economic Policy, usually chaired by the deputy prime minister, was supported by a standing Officials Economic Committee, itself served by a standing working party. Officials participated in discussion in the Cabinet Economic Committee, which met monthly. ${ }^{69}$

When Shanahan, in his capacity as secretary to Cabinet, called on the secretary to the Treasury in 1952 to discuss the arrangements for servicing the Cabinet Economic Committee, Ashwin agreed to Shanahan's proposals with one exception - he was insistent that the secretariat for the Officials Committee and the Working Party should be in the Treasury, not the Cabinet Secretariat. ${ }^{70}$ From the outset, the Treasury chaired and provided the secretarial services for the committee and the working party (and signed all submissions to the Cabinet Committee). ${ }^{71}$

On some issues from the 1940s to the 1980s there was a long-standing divergence between departmental 'lines' - notably on industrial policy and border protection between the Treasury and Industries and Commerce - and some 'patch protection' between Industries and Commerce and Foreign Affairs on

67 B. Galvin, Policy Co-ordination, Public Sector and Government (Wellington: Institute of Policy Studies, 1991), 12; Baker, The New Zealand People at War, 569.

68 McKinnon, Treasury, 187.

69 For a contemporary discussion of the official economic policy making arrangements in the early 1950s see G.J. Schmidt, 'Some Administrative Problems Associated with a Vulnerable Balance of Payments', Paper presented for Diploma of Public Administration, Victoria University of Wellington (1952).

70 Personal information: H.G. Lang ONZ, Secretary to the Treasury (1967-76).

71 Other departments represented on the Officials Economic Committee (OEC) were Industries and Commerce (from 1972 Trade and Industry), Agriculture, External Affairs (from 1972 Ministry of Foreign Affairs), Customs and Statistics. The Reserve Bank attended when internal economic policy was under discussion. Permanent heads or their deputies usually attended meetings of the OEC; the working party was chaired by a divisional director in the Treasury. The range of topics was very wide with a heavy emphasis on overseas trade policy as well as the more obvious matters such as regular reporting on the economic situation and the overseas exchange forecasts. Significantly, the budget and taxation fell outside the scope of the committee - these were matters for the Minister of Finance and the Treasury. 
trade policy. ${ }^{72}$ Nonetheless, the machinery of coordination among departments, especially on economic matters, through the post-war period until the fourth Labour (Lange) Government's 'Revolution' in the 1980s can be given a strong pass assessment.

\section{The post-war public service}

On the cessation of hostilities an immediate problem facing the government and the controlling authority, the Public Service Commission, was absorption into the permanent staff of 'the huge temporary army of public servants' that had entered the public service during the war. ${ }^{73}$ This was not an easy task. The Public Service Commission had to balance the claims of the temporaries - often not meeting the criteria for permanent employment - with the equity promised to those returning from military service. After intense negotiations with the public service trade union, the Public Service Association (PSA) whose significance in this period cannot be overstated - the necessary statutory amendments were enacted in the Public Service Amendment Act (1946).

The principal change ${ }^{74}$ ushered in by the 1946 amendment - the first major change to the governing statute since 1912 - was replacement of the sole Public Service commissioner by a three-man commission, one of whom was to be a representative of the PSA (following a precedent set in some Australian states). ${ }^{75}$ Appointed as chairman for a seven-year term was the last of the 'mandarins' in this particular narrative, Dr R.M. (Dick) Campbell - 'an unusual choice', in the words of the State Service Commission's historian. ${ }^{76}$ Campbell, at the time, as he had been for some 10 years, official secretary (effectively deputy high commissioner) in London, had worked with Reform Party minister Coates during the 1920s and 1930s (latterly as one of the 'brains trust'). ${ }^{77}$ An economist

72 T. Woodfield, Against the Odds: Negotiating for New Zealand's Future (Palmerston North: Dunmore Press, 2008).

73 J.H. Boyes, Public Service Commissioner, quoted by Alan Henderson, The Quest for Efficiency: The Origins of the State Service Commission (Wellington: Historical Branch, Department of Internal Affairs, 1990), 173.

74 Other changes were the opening up in a limited way of the appointment of people from outside the service who were shown to be 'in great degree' more suitable than applicants from within, and the exemption of a number of Permanent Head positions from the Public Service Act - thus leaving the way open for political appointments. (Those excluded were the Secretary to the Treasury, the Solicitor-General, the Secretary of External Affairs, the head of the Prime Minister's Department, the Commissioner of Works, the Director of Broadcasting and the Commissioner of Supply.)

75 Webb, 'Politics and Administration', 282.

76 Henderson, The Quest for Efficiency, 189.

77 In 1934-35 Gordon Coates, as minister of finance, employed in his private office advisers who collectively became known as the 'Brains Trust'. They were Campbell, Professor Horace Belshaw from Auckland University (with a Cambridge doctorate and an association with Keynes), and Dr W.B. Sutch, a 27-year-old graduate of Columbia University and later secretary of Industries and Commerce (1958-65). 
(with a doctorate from the London School of Economics), he had no experience of administration on the scale of the public service. Fortunately, another commissioner was very experienced; George Bolt had been with the commission since 1916.

There was no doubting Campbell's sharpness of mind (and of pen). '[H]e was consistently innovative, if unpredictable and unorthodox in his methods. In matters of efficiency and economy, he was a breath of fresh air, with his enthusiasm to promote change tempered constructively by Bolt's experience. ${ }^{78}$ J.K. (later Sir Jack) Hunn, then on the staff of the commission and later a commissioner, observed that 'Dick Campbell was an inspirational force in either trying out ideas of his own or invigorating others. He was the soul of unorthodoxy ... Dick Campbell tried hard to humanize the Public Service but it was a Sisyphean uphill struggle. ${ }^{.79}$

What was the direction of change in which Campbell sought to take the service? Campbell placed considerable emphasis on improving departmental efficiency and introduced the O\&M ('Organisation and Methods') approach thus emulating innovations of the British Treasury. Long overdue, the commission also embarked down the devolution route, delegating personnel authority to departments and establishing the commission's presence in offices in Auckland and Christchurch. More controversially, Campbell sought to open up the service with proposals to remove provisions that were solidly embedded in the regime. Among these were abolition of appeal rights above a certain salary ceiling and reduction of the statutory protection against competition from outside applicants; opposed by the assertive PSA, neither proceeded into legislation.

In the longer view, the most interesting questions that might be asked about the New Zealand Public Service of the immediate post-war period concern its quality. Leicester Webb, though not unkind, had been a consistent critic through the 1940s:

The genius of the New Zealanders expresses itself in the sphere of government, not in a capacity for solving difficult problems of sociology or economics, but in a capacity for carrying through successfully projects requiring organising ability and technical skill and resource... since the nature of the problem is clearly defined and the type of ability needed for its solution easily measurable. But when the task involves excursions into abstract thought and calls for ability of the type which is difficult either to define or measure, government in New Zealand is

78 Henderson, The Quest for Efficiency, 191.

79 J.K. Hunn, Not Only Affairs of State; An Autobiography (Palmerston North: Dunmore Press, 1982), 55 , $62-3$. 
frequently at a loss and tends either to fall back on shallow definitions of common sense or to become dominated by ideas which are ingenious and misleading simplifications. ${ }^{80}$

In 1944, Webb defined 'two public services in New Zealand today': one, the new agencies set up to deal with the issues of wartime 'staffed in a large measure by men and women without public service training'; and the 'old-fashioned departments', a public service that had been

markedly reluctant to prepare itself for the work of regulating or actively directing economic enterprises; in these respects it is still very much the product of the reforms of 1912 - reforms conceived by men whose instinct was to set the narrowest possible limits to State activity. ${ }^{81}$

While Webb was focusing particularly on economic policy making, Lipson $^{82}$ in 1948 raised a general concern about the impact of an undue preoccupation with a 'perverted equalitarianism' ${ }^{83}$

New Zealand is notoriously ungenerous to talent. In its anxiety to raise minima, the country has deemed it necessary to lower maxima ... There is not enough encouragement for each to do his best and for the ablest to display their full capacity. Everything tends toward a norm, and deviation from the average becomes a cardinal $\sin .^{84}$

This was to return to an issue that was high in the agenda in the years immediately before the Second World War, namely the perceived disadvantages faced by graduates who, after full-time study, sought to join the state services; they could be appointed only if there were no suitable internal candidate. While there was a place for science and professional graduates, this was not the case for those who were majoring in arts or 'cultural' ${ }^{\prime 5}$ disciplines. Discussion between the university and the Public Service Commission continued until the war. The minister of education (Fraser) set up a representative committee, chaired by the vice-chancellor of the University of New Zealand, Professor T.A. (later Sir Thomas) Hunter, and including the ubiquitous Bernard Ashwin. It did not report and was overtaken by the outbreak of war. The commission had continued to emphasise the value of work experience - from cadet to permanent head.

\footnotetext{
80 L.C. Webb, Government in New Zealand (Wellington: Department of Internal Affairs, 1940), 158-9.

81 L.C. Webb, 'The Future of Wartime Control', NZJPA, 7, no. 1 (September 1944), 17.

82 Leslie Lipson, an Oxford graduate teaching at the University of Chicago, was appointed in 1938, at the age of 26, as the first Professor of Political Science at Victoria University College, Wellington.

83 L. Lipson, The Politics of Equality: New Zealand's Adventures in Democracy (Chicago: Chicago University Press, 1948), 456.

84 Ibid.

85 Ibid., 491.
} 
The recently formed Institute of Public Administration submitted that 'preferential treatment for the university graduate, such as is given in the administrative grade in England is not suitable to New Zealand conditions' ${ }^{86}$

Any suggestion that New Zealand initiate some aspect of the administrative class at once runs afoul of strong antipathy to the British method of recruitment ... the Public Service Association will assail this insidious advocacy of a privileged class ... In general, those who have joined the service at the age of eighteen or under have felt that they had a prior claim on opportunities for promotion and have sought to exclude the holders of nonprofessional degrees. ${ }^{87}$

The view of the Public Service Commission (PSC), the Institute of Public Administration and, no doubt, the generality of public servants appeared to have been shared by Labour ministers. McIntosh's efforts after 1943 to establish a distinctly New Zealand diplomatic service received no encouragement from Peter Fraser who decided that no permanent appointments should be made to External Affairs until the returned servicemen became available. ${ }^{88}$ (From 1946 External Affairs, almost alone among departments, recruited a very high quality of graduates as well as some outstanding officers discharged from the military.)

While arts graduates were not welcomed into the New Zealand Public Service until the 1950s, accountants were ranked highly. Before the war the professional accountant's qualification (Accts. Prof) was earned by part-time study at private colleges rather than the university (which took over accountancy education in 1946). By the end of the 1930s about 65 public servants acquired accountancy diplomas annually while something like 40 gained qualifications in other fields. 'Usually the expert was employed on expert work but accountancy training became a recognised qualification for advancement on administrative duties. ${ }^{89}$

After the war the reliance on accountancy began to be questioned. As Sam Barnett, then superintendent of Staff Training in the PSC and later secretary of Justice, wrote in the Institute of Public Administration's journal in 1946, 'the education of the Public Service in New Zealand has for the past 30 years been conducted under the auspices of the N.Z. Society of Accountants, if it can be said that that professional body educates anyone'.$^{90}$ Nonetheless, Acct. Prof. remained a common hallmark of a very high proportion of senior management in the New Zealand Public Service into the 1960s at least.

\footnotetext{
86 J.R. Martin, Spirit of Service: A History of the Institute of Public Administration New Zealand (Wellington: IPANZ, 2006), 23.

87 Lipson, The Politics of Equality, 457-8.

88 McIntosh, 'Origins of the Department of External Affairs', 19.

89 Polaschek, Government Administration in New Zealand, 112.

90 S.T. Barnett, 'Education for the Public Service', NZJPA, 9, no. 1 (1946), 6; quoted by Polaschek, Government Administration in New Zealand, 122.
} 
An important development in the preparation of officials for leadership came with the establishment of the Department of Political Science and School of Public Administration at Victoria University, Wellington, in 1939. Strongly urged by the Institute of Public Administration and supported by the PSC, the School inaugurated the Diploma of Public Administration (DPA) that continued until the 1970s when the Master of Public Policy (MPP) replaced it. One course ran in 1940-41. After wartime suspension, the DPA resumed in 1947. The initial staff was Leslie Lipson and R.S. Parker from the University of Sydney (later to succeed Lipson as professor). Of the eight students on the first course, two became chairmen of the State Services Commission, one headed the Post Office, one became the secretary of Industries and Commerce, one headed the South Pacific Commission, and one became Professor of Political Science at Victoria. Later courses, if not quite matching this record, provided a number of permanent heads and their deputies.

\section{Conclusion}

From the distance of more than 60 years, revisiting the aftermath of the Second World War provides some insights into the development of the governance of New Zealand - particularly the public service - in the succeeding decades. An obvious, but often forgotten, proposition is that history is continuous. In this case, we cannot ignore the experience of the war or the long-term impact of the 1930s. First, the damage to New Zealand society caused by the Depression and prolonged and widespread unemployment. Second, the first Labour Government's willing resort to instruments of the state - willing but driven by the issues rather than doctrinaire socialist ideology. And, third, the exchange crisis of 1938 and the imposition of controls at the frontier.

Writing in 1953, Leicester Webb correctly observed that 'the content of political action in our time is almost wholly economic'. ${ }^{91}$ This chapter has, therefore, concentrated on the post-war challenges to the system of governance posed by, first, economic management in the short term ('insulationism' and 'stabilisation') and, secondly, the issues of development for the longer term ('planning'). There are, however, other issues that could have repaid more detailed examination: the issues raised by the urbanisation of Maori, for instance; the expansion of the welfare state; or the 'formulation of an independent foreign policy' ${ }^{92}$ But the focus of this chapter has been on the way in which policy was made and executed rather than on its substance - on the machinery, mechanics and style of government rather than the outcomes.

91 Webb, 'The Making of Economic Policy', 12.

92 McIntosh, 'Origins of the Department of External Affairs'. 
In political terms exploration of these matters has been almost exclusively with the latter period in office of the first Labour Government (1935-49). The general election of late 1949 brought the National Government to power. National occupied the Treasury benches for 27 of the next 34 years and this study identifies the central core of continuity in style and approach of Labour and National governments. This is thrown into relief by the contrast with the 'revolutionary' years between 1984 and 1990 when the fourth Labour Government (Lange, Palmer, Moore) was in office.

As Simkin observed, 'New Zealand is a singularly pure example of a dependent economy' ${ }^{93}$ From the 1930s on, New Zealand governments sought to 'insulate' the country from the effects of the instability that went with dependence. Creation of the Reserve Bank in 1934; the advent of exchange and import controls to deal with the 1938 run on the currency; the action taken by Labour to centralise commodity marketing and introduce guaranteed dairy prices; and the Social Security Act 1938 all symbolise acceptance of the role of the state in mitigating external influences on New Zealand's welfare. Thus, when the resources of the country were mobilised to meet New Zealand's wartime obligations, the basic elements of the machinery of 'insulation' were already in place.

Central to economic management from 1942 through the 1940s was the Economic Stabilisation Commission (ESC). Its all-embracing range over the activities of producers and consumers was, during the war, effectively under the control of a triumvirate of appointed office-holders: Ashwin together with representatives of the labour movement (F.P. Walsh) and the farming industries. Ashwin and Walsh during 1945 worked on a post-war stabilisation regime, retaining most controls, which Walsh, with difficulty, sold to the union movement - which was, however, to chafe at the restraint applied to wages that led to the confrontation between the watersiders and the National Government in $1951 . .^{94}$

Ashwin and Walsh were both close to the prime minister, Peter Fraser; Ashwin saw him almost every day during the war. ${ }^{95}$ '[Fraser] established a working relationship with the able if unlovable F.P. Walsh of the Seamen's Union at an early stage in the life of the government.. ${ }^{96}$ Ashwin was directly responsible to the minister of finance but Nash was in Washington DC between 1942 and 1944.

The tripartite nature of the ESC signals the crucial role played in New Zealand public policy and politics in the post-war period by 'the three great economic

93 C.G. Simkin, The Instability of a Dependent Economy: Economic Fluctuations in New Zealand 1840-1914 (London: Oxford University Press, 1951), v.

94 Bassett and King, Tomorrow Comes the Song, 298.

95 B. Easton, 'Fraser and the Development of the Nation-Building State', 125; quoting from a 1970 interview of Ashwin by John Henderson.

96 M. Bassett, 'The Political Context of the Prime-Ministerial Years', in M. Clark, ed., Peter Fraser, Master Politician (Wellington: Dunmore Press, 1998), 47. 
pressure groups, the Federation of Labour, Federated Farmers, and the Employers' Federation $^{\prime 97}$ - with the government holding the ring. Parallel with the ESC, and central in industrial relations until the 1980s, was the Arbitration Court. Providing an essential background was, as John Roberts argued persuasively, 'a society of fair shares' that endured until the 1980s upheaval. ${ }^{98}$

The Economic Stabilisation Commission did not survive the arrival of the National Government. But the significant array of controls that remained and the influence of the officials who had served their formative years in the ESC ensured that its influence continued to be felt. The policy of insulationism in the cause of stability also persisted. Balance of payments crises in 1957-58 and at intervals through the 1960s and 1970s meant that import and exchange controls, administered with varying degrees of severity, remained in place. Similarly, persistent bouts of inflation saw governments of different persuasions intensify price and incomes controls. Pragmatic recourse to the instruments of the stabilisation policies of the 1940s was the hallmark of economic policy until the 1980s. At the same time, what can be identified broadly as Keynesian fiscal and monetary policies were subscribed to.

Taking the longer view, at one level, wartime initiatives resulted in a 'permanent' 99 addition to the machinery of government - the role of the Ministry of Works as a planning influence on physical investment. ${ }^{100}$

At a broader level of national planning of the economy, to which some at least believed the short-lived Organisation for National Development (OND) should aspire, the record is patchy at best. In bureaucratic terms, the demise of the OND can be attributed to the ability of Ashwin (and the Treasury) in particular to influence government thinking. They probably shared Leicester Webb's judgment expressed in 1947 that 'perhaps because the scope of its activities was both too wide and too nebulous, it did not have much effect on administration and was finally allowed to lapse.'101 The output of the OND was likely to have been contrasted with the very practical responsibilities being assumed by the Ministry of Works.

At the political level, the Fraser Government was well aware that once the war had ended, there would be strong pressures from the business community in

97 J. Roberts, 'Society and its Politics', in I. Wards, ed., Thirteen Facets: The Silver Jubilee Essays Surveying the New Elizabethan Age; A Period of Unprecedented Change (Wellington: Government Printer, 1978), 71.

98 Ibid., 73.

99 The Ministry of Works was privatised in 1988.

100 For a discussion of the Ministry's role see R. Noonan, By Design and Polaschek, Government Administration, 260-70.

101 Webb, 'Politics and Administration', 288. 
particular, in concert with the National Party, to reduce the extent of controls. ${ }^{102}$ The narrow majority achieved at the 1946 general election underlined the first Labour Government's declining hold on office. ${ }^{103}$ But the OND would have converted New Zealand's economic policy into a centrally coordinated detailed plan. Commenting on a 1944 document, Interim Report on Post-War Reconstruction and National Development, J.V.T. Baker, historian of the war economy (and later government statistician), observed 'though the Labour party has often been accused of being socialistic, it was not ready for this.. ${ }^{104}$

A striking feature through this period is the continuity of public service leadership. Ashwin in the Treasury was a towering figure for three decades. McIntosh and Shanahan were at the centre of New Zealand governance from the outbreak of war to the 1960s. Others such as Moriarty, Lang and Lough were central figures in economic policy making into the 1970s. The same continuity features in other areas of public policy. Dr C.E. Beeby, director of Education, 1940-60, was synonymous with education in New Zealand for more than 20 years. Sir Joseph Heenan, secretary of Internal Affairs (1935-49), was the Labour Government's 'go to' person in many matters. In the labour and employment field, James Hunter, then Herbert Bockett, played leading roles from the 1930s to the mid-1960s. ${ }^{105}$ A.R. (Pat) Entrican ${ }^{106}$ was director of Forests from 1939 to 1961 and E.J. Fawcett, director-general of Agriculture from 1943 to 1957. ${ }^{107}$ All made major contributions and were individuals with personalities that could not be ignored. ${ }^{108}$

Others have identified the contribution of this group of key public servants to governance in the 1940s and 1950s. John Roberts, for example, writing in 1978 in the aftermath of the first oil crisis, was pessimistic about the prospects for reform in economic management in New Zealand 'in the face of the inert administrative system'.

New Zealand has an honest, intelligent and public bureaucracy which is incapable of major reform. This is largely due to the insulation of the service from politics instituted in 1912 and confirmed in 1962. The effects were masked in the crisis of the depression and war, partly

\footnotetext{
102 The public too was restless. As early as 1944, Webb noted that ' $\mathrm{t}$ ] $\mathrm{here}$ are signs that the public generally, irrespective of their economic interests or political opinions, have grown very weary of coupons, forms and regulations'. Webb, 'The Future of Wartime Control', 10.

103 Labour had a majority of four - the four Maori seats. Bassett and King, Tomorrow Comes the Song, 312.

104 Baker, The New Zealand People at War, 531.

105 J.E. Martin, Holding the Balance: A History of New Zealand's Department of Labour 1891-1995 (Canterbury: Canterbury University Press, 1996), 235.

106 J.R. Martin, 'Entrican, Alexander Robert', in The Dictionary of New Zealand Biography, Vol. 5, (2000), $164-5$.

107 Tony Nightingale, White Collars and Gumboots: A History of the Ministry of Agriculture and Fisheries 1892-1992 (Wellington: Dunmore Press, 1992), 237-8.

108 Entrican, for example, wore bow ties and a broad-brimmed cowboy-style hat.
} 
because the Labour Party simply circumvented the rules and brought their men into administrative power, and partly because obsessive institutional separatism had to be abandoned in the face of wartime exigencies. ${ }^{109}$

Certainly, these outstanding public servants give the lie to the generally held belief that appointments in the 'old' public service were made in accordance with 'Buggins' turn in the five years or so before superannuation became available. Ashwin was appointed as secretary to the Treasury at the age of 42; Berendsen, secretary of External Affairs and head of the Prime Minister's Department at 38 and 42 respectively; McIntosh, to these positions at 37 and 39 respectively; Beeby, director of Education at 37; Heenan, secretary of Internal Affairs at 47, and Entrican director of Forests at 41.

It is beyond dispute that these public service leaders of the 1940s and 1950s all enjoyed a close relationship with Peter Fraser. Equally, there are indications that the same permanent heads may not have had a comparably easy relationship with the Holland-led National Government after 1949. One overseas commentator, after spending some time in New Zealand, noted that 'like the Republicans in 1953 [in the United States], the Nationalists in 1950 were imbued with a suspicion of, almost a hostility towards, the administrators' ${ }^{110}$ But this can be attributed, on the experience of other changes of government after a long period, to quite understandable doubts about the enthusiasm for new masters that would be shown by those so close to the previous administration. Perhaps not surprisingly, by 1949 only one permanent head had been in office before Labour had come to power in 1935.

Nevertheless, all the permanent heads mentioned above except Beeby (who had been director of the Council of Educational Research until invited by Fraser to apply for the position of assistant director of Education with the expectation of ascending to director $)^{111}$ were career public servants. All except Campbell (appointed as chairman of the Public Service Commission by the governorgeneral on the advice of ministers in accord with statute) were appointed by the Commission.

Since the 1980s the bureaucratic memory in New Zealand has become focused on the present and what came immediately before. The people who form the subject of this essay, and the context in which they carried out their important

\footnotetext{
109 Roberts, 'Society and its Politics', 96 (emphasis added).

110 Political scientist, P. Campbell, 'Politicians, Public Servants and the People in New Zealand: II', Political Studies, 4, no. 1 (February, 1956), 21, quoted by McKinnon, Treasury, 206. Also conversation with Dr Beeby. 111 Beeby was appointed under the usual public service procedures, a point he emphasised later in his life. See Noeline Alcorn, To the Fullest Extent of his Powers: C.E. Beeby's Life in Education (Wellington: Victoria University of Wellington, 1999), 90-2. The influence of the prime minister, is, however, suggested by a reference to 'Peter Fraser's stacking the interview panel to ensure that C.E. Beeby became Director of Education'. I. Carter, Gadfly: The Life and Times of James Shelley (Auckland: Auckland University Press, 1991), 224.
} 
public responsibilities, are virtually forgotten. Nonetheless, an exploration of governance in the immediate post-war period has served to emphasise the continuity in public service as well as acknowledging the contribution to New Zealand society of those who have gone before. 
This text is taken from The Seven Dwarfs and the Age of the Mandarins: Australian Government Administration in the Post-War Reconstruction Era, edited by Samuel Furphy, published 2015 by ANU Press, The Australian National University, Canberra, Australia. 